\title{
ANALISIS KEASLIAN CITRA DENGAN MENGGUNAKAN EXIF METADATA
}

\author{
Alma Apriliani ${ }^{1}$, Kartika Hijjayanti ${ }^{2}$, Suhairoh $^{3}$
}

${ }^{1,2,3}$ Fakultas Ilmu Komputer, Universitas Singaperbangsa Karawang

Jl. H.S. Ronggowaluyo, Telukjambe Timur, Karawang

1alma.16032@student.unsika.ac.id, ${ }^{2}$ kartika.16129@student.unsika.ac.id, ${ }^{3}$ suhairoh.16211@student.unsika.ac.id

\begin{abstract}
Abstrak - Teknologi pada saat ini sudah berkembang sangat pesat, sehingga pengaruh dalam kehidupan sehari-hari memiliki banyak efek positif dan negatif dalam penerapannya. Perkembangan dunia digital dengan kecanggihan perangkatnya saat ini juga disalahgunakan sebagai salah satu tindak kejahatan yaitu memanipulasi gambar yang bertujuan menguntungkan pelaku seperti halnya melakukan bisnis online dengan penipuan gambar yang tidak sesuai atau mempromosikan produk dengan pemalsuan gambar sebagai hak milik, sehingga hal ini berakibat merugikan orang lain. Digital forensik merupakan penggunaan prosedur dalam pengujian suatu sistem komputer untuk mengekstrak barang bukti suatu tindakan. Sehingga penyelidikan keaslian citra ini menggunakan Algoritma EXIF Metadata agar informasi yang didapat terstruktur sehingga mendapatkan kesimpulan dari penyelidikan keaslian citra dengan adanya informasi software sebagai alat pemalsuan citra.
\end{abstract}

Kata Kunci- Analisis, Digital Forensik, Gambar, Metadata.

Abstract-Technology at this time has developed very rapidly, so the influence in daily life has many positive and negative effects in its application. The development of the digital world with the sophistication of the device is currently also misused as a crime that is manipulating images that aim to benefit the perpetrators as well as doing online business with inappropriate image fraud or promoting products with counterfeiting images as property rights, so this results in detrimental to others. Digital forensics is the use of procedures in testing a computer system to extract evidence of an action. So that the investigation of the authenticity of this image uses the EXIF Metadata Algorithm so that the information can be structured so that it gets a conclusion from the investigation of the authenticity of the image with the presence of software information as a means of image forgery.

Keywords-Analysis, Digital Forensics, Metadata, Picture.

\section{PENDAHULUAN}

Perkembangan dunia digital yang pesat saat ini membawa dampak positif yang beragam seperti mudahnya pengaksesan kepada objek digital dan banyaknya platform yang mendukung proses pengolahan objek digital tersebut. Disamping menghadirkan dampak positif tersebut, perkembangan dunia digital juga membawa dampak yang tidak baik. Pemanfaatan platform digital yang mengarah ke area negatif dapat membawa dampak bagi masyarakat yang nantinya akan mengakses objek digital tersebut sebagai sumber informasinya.

Kemajuan dunia digital mendukung proses pengolahan citra dapat dilakukan dengan mudah menggunakan ilmu komputer. Namun banyak ditemukan kasus-kasus para oknum kejahatan yang melakukan manipulasi citra yang bertujuan untuk menyebarkan informasi menyesatkan, sehingga akan menimbulkan perselisihan.

Proses pembuktian citra digital yang telah dimanipulasi biasa dilakukan dengan teknik menganalisis kesamaan konten dalam citra untuk mengetahui apakah ditemukan sebuah perbedaan diantara keduanya. Selain teknik tersebut, juga terdapat teknik lain yang dapat dilakukan untuk mengetahui apakah sebuah citra telah melalui proses manipulasi atau perubahan. Teknik tersebut adalah teknik pendekatan metadata. Dalam teknik ini dilakukan pengecekkan metadata dari suatu objek digital yang kemudian informasi tersebut dapat berguna untuk menjelaskan kondisi dari objek digital tersebut.

\section{LANDASAN TEORI}

\section{A. Citra Digital}

Citra merupakan sebuah gambar yang merepresentasikan suatu objek. Citra digital merupakan representasi objek yang dapat diolah di dalam perangkat komputer. Citra digital diperoleh dari peralatan digital seperti kamera digital sehingga dapat secara langsung diolah di dalam komputer. Penyebab citra yang dihasilkan dari peralatan digital dapat secara langsung diolah di dalam komputer adalah terdapat sistem sampling dan kuantisasi yang berguna untuk mengubah citra kontinu menjadi digital serta mengubah 
intensitas analog menjadi intensitas diskrit di dalamnya. Dalam proses sistem sampling dilakukan pembagian citra analog menjadi sejumlah $\mathrm{m}$ baris dan $\mathrm{n}$ kolom sehingga menghasilkan citra digital. Sedangkan dengan melakukan proses sistem kuantisasi akan dihasilkan gradasi warna yang sesuai dengan kebutuhan [1]. Terdapat beberapa tipe citra yang umum digunakan:

1) Citra Biner: Citra biner merupakan citra yang memiliki 2 warna yakni hitam dan putih. Tiap piksel dalam citra biner hanya membutuhkan 1 bit memori.

2) Citra Grayscale: Citra grayscale atau citra keabuan merupakan citra yang memiliki intensitas piksel antara 0 hingga 255. Setiap piksel dalam citra grayscale membutuhkan 8 bit dalam memori.

3) Citra Warna: Citra warna merupakan citra yang pada masing-masing pikselnya memiliki tiga komponen warna yaitu red, green, dan blue. Format file grafis menyimpan citra warna sebagai citra 24 bit.

\section{B. Citra Forensik}

Kemajuan software editing memudahkan bagi seseorang untuk memanipulasi citra asli tanpa meninggalkan bekas manipulasinya. Citra forensik merupakan keahlian untuk mengidentifikasi, menganalisis dan menguji bukti pada citra digital. Manipulasi citra dapat dikategorikan menjadi tiga jenis yakni splicing citra, pemalsuan citra copy-move, dan citra retouching [2]. Berikut dijelaskan masing-masing pengertian dari ketiga jenis manipulasi citra:

1) Citra Splicing: Citra splicing adalah proses menggabungkan dua atau lebih citra untuk membuat citra baru. Sebuah wilayah tertentu disalin dari satu citra dan disisipkan ke lain untuk membentuk citra yang berbeda.

2) Pemalsuan Citra Copy-Move: Pemalsuan citra copy-move adalah jenis umum dari proses manipulasi citra. Proses ini melibatkan penyalinan dan penyisipan dalam citra yang sama. Wilayah yang disalin umumnya dimodifikasi dengan operasi seperti scaling, rotasi, dan menambahkan suara untuk membaur wilayah yang dimanipulasi dengan daerah sekitarnya.

3) Citra Retouching: Citra retouching adalah proses mengubah piksel dengan menyalin sesuai dengan piksel sekitarnya. Hal ini dapat meningkatkan atau mengurangi beberapa fitur dari citra asli tanpa mengubah keaslian yang sebenarnya. Citra retouching biasa dilakukan oleh para editor majalah untuk membuat citra lebih menarik.

\section{EXIF Metadata}

Exchangeable Image File atau EXIF merupakan data yang berisi tentang informasi pada sebuah gambar. Metadata EXIF merupakan standar yang digunakan untuk tag file gambar dan audio yang dibuat oleh perangkat dan aplikasi. Biasanya berisi tentang informasi eksposure seperti shutter speed, ISO, aperture, white balance, metering, tanggal dan jam pemotretan, dan focal length lensa yang mana data ini tidak bisa didapatkan jika menggunakan kamera analog [3]. Metadata berfungsi untuk menemukan atau menemukan kembali, serta menjelaskan informasi yang terstruktur mengenai sebuah gambar [4].

\section{Python}

Python merupakan bahasa pemrograman interpretatif yang berfokus pada keterbacaan kode. Python diklaim sebagai bahasa pemrograman yang memiliki kode-kode pemrograman yang jelas, lengkap, dan mudah untuk dipahami. Python secara umum berbentuk pemrograman berorientasi objek, pemrograman imperatif, dan pemrograman fungsional. Python dapat digunakan dalam berbagai keperluan pengembangan perangkat lunak dan dapat berjalan di berbagai platform sistem operasi seperti Linux, Windows, Mac OS X, dan Symbian [5].

Bahasa pemrograman Python pertama kali diperkenalkan pada tahun 1991 oleh Guido van Rossum sebagai web development software development, mathematics, dan system scripting. Python dapat digunakan pada server untuk membuat aplikasi berbasis web, dapat dihubungkan dengan sistem basis data, dapat membaca dan memodifikasi file, menangani big data dan aplikasi matematika yang kompleks [6].

\section{E. Extreme Programming}

Extreme Programming atau XP merupakan salah satu metodologi rekayasa perangkat lunak yang digunakan untuk proses pengembangan aplikasi oleh developer. XP pertama kali diperkenalkan oleh Kent Beck ketika ia sedang menangani sebuah proyek penggajian. XP cocok untuk digunakan pada proses pengembangan proyek yang memerlukan adaptasi cepat dalam perubahan-perubahan yang terjadi selama pengembangan aplikasi. Dalam metode XP dilakukan tahapan planning, design, coding, dan testing [7]. Tahapan pengembangan perangkat lunak dengan XP adalah sebagai berikut:

1) Planning: Tahap planning atau perencanaan dimulai dengan pemahaman konteks bisnis dari aplikasi, mendefinisikan keluaran, fitur yang ada dalam perangkat lunak, fungsi dari perangkat lunak yang dibuat, penentuan waktu dan biaya yang dibutuhkan, serta alur pengembangan aplikasi.

2) Design: Pada tahap ini dilakukan pembuatan desain aplikasi secara sederhana.

3) Coding: Dilakukan implementasi desain ke dalam bentuk kode program.

4) Testing: Pada tahap ini difokuskan untuk melakukan pengujian fitur-fitur yang ada di dalam aplikasi, sehingga tidak ditemukan kesalahan dan aplikasi yang telah dibuat sesuai dengan proses bisnis yang telah direncankan. 


\section{METODE PENELITIAN}

Metode yang dilakukan dalam penelitian ini bertujuan untuk mencari informasi mengenai gambar yang telah dimodifikasi. Metode yang digunakan yaitu Extreme Programming dengan tahapan sebagai berikut:

Page | 86

1) Planning: Dalam tahap ini peneliti melakukan perancangan awal atau pemahaman algoritma serta metode yang akan digunakan dalam penelitian. Serta pencarian study literatur yang bertujuan untuk mendukung data yang didapat dari referensi dan literatur yang berhubungan dengan penulisan penelitian yang dibahas. Pada tahap ini juga dilakukannya pengumpulan data yang berasal dari informasi mengenai suatu peristiwa yang dicurigai dalam bentuk gambar.

2) Design: Pada tahap design dibuat perancangan sistem berupa struktur algoritma berupa flowchart.

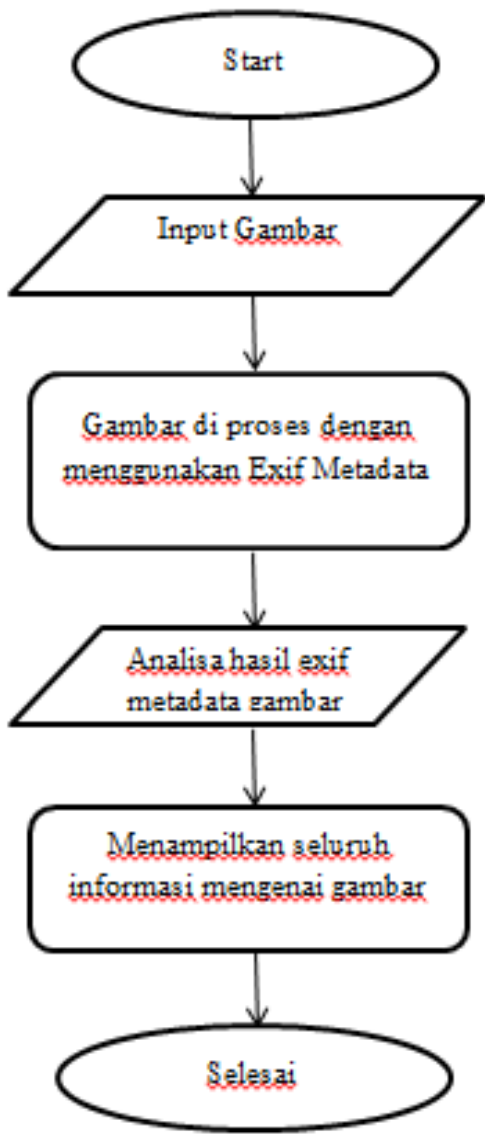

Gbr. 1 Flowchart Identifikasi Gambar

3) Coding: Pada tahap ini merupakan pengimplementasi dari desain yang telah dibuat dalam bentuk kode program dengan menggunakan bahasa pemrograman Python.

4) Testing: Tahap testing merupakan proses pengujian sistem yang telah dibuat oleh peneliti dengan bertujuan dapat mengevaluasi bentuk sistem yang lebih baik untuk dipergunakan.

\section{IV.HASIL DAN PEMBAHASAN}

Program Aplikasi EXIF Metadata dibuat dengan bahasa pemrograman Python dan menggunakan library Pillow atau Python Imaging Library. Berikut ini merupakan script program aplikasi tersebut:

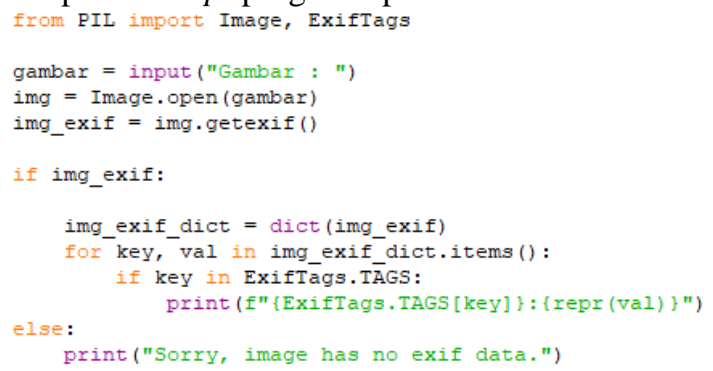

Gbr. 2 Script Program EXIF Metadata

Pada tahap selanjutnya program aplikasi yang telah dibuat diimplementasikan pada gambar yang telah dimanipulasi dan gambar yang belum dimanipulasi. Berikut ini merupakan tahapan dari penggunaan sistem untuk membaca metadata pada gambar:

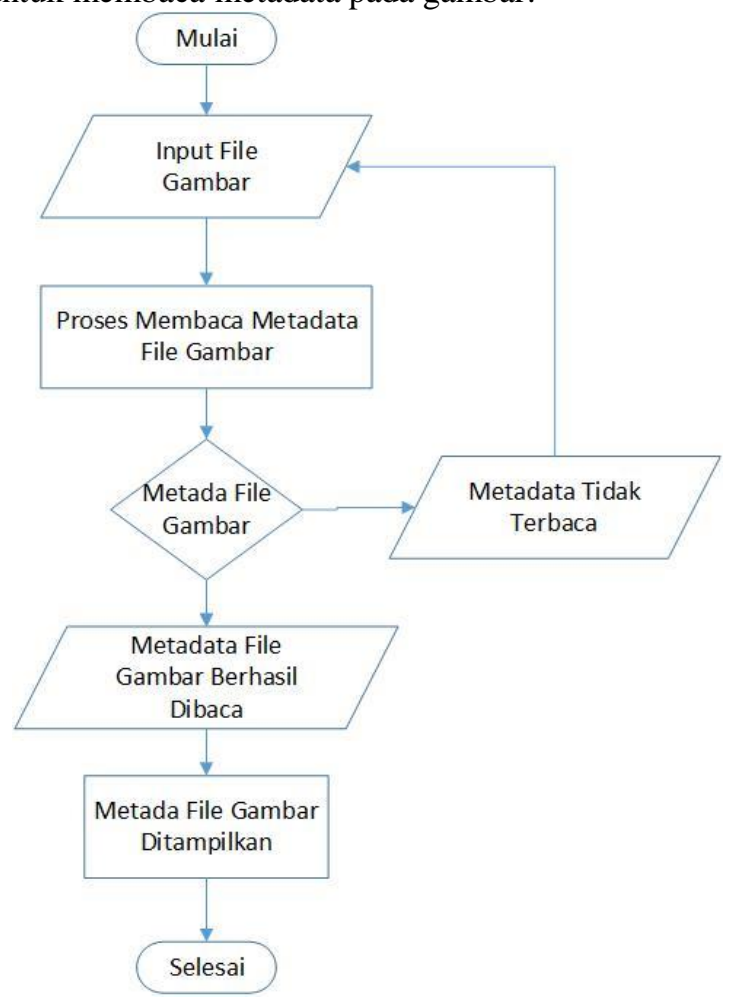

Gbr. 3 Flowchart Membaca Metadata File Gambar

Pada tahap pertama dilakukan input gambar. Gambar yang diinput adalah gambar yang belum dan sudah dimanipulasi. 


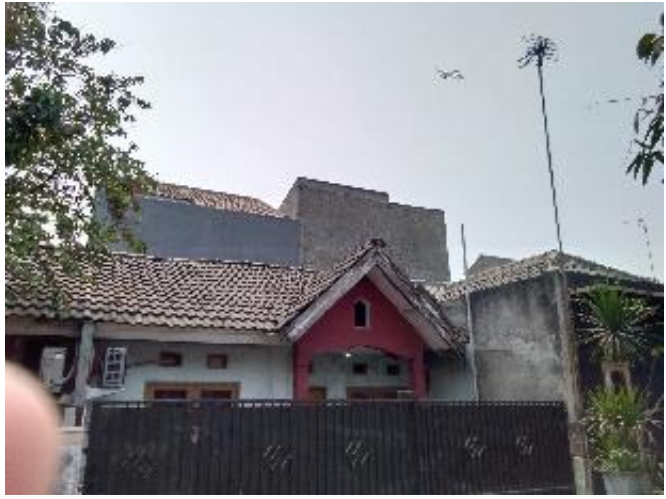

Gbr. 4 Gambar yang Telah Dimanipulasi

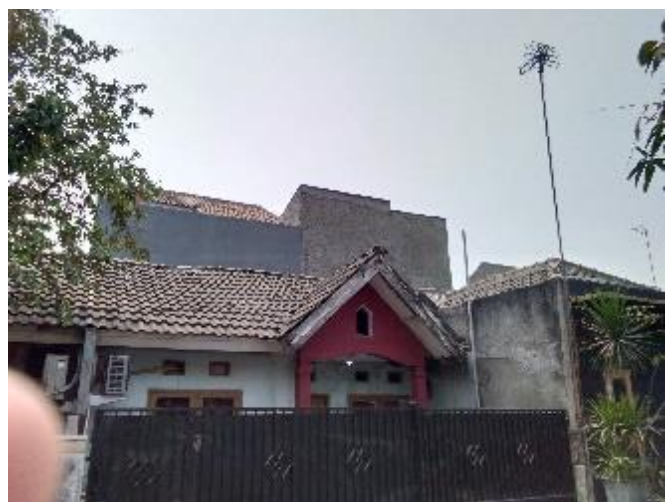

Gbr. 5 Gambar yang Belum Dimanipulasi

Program akan membaca metadata yang terdapat pada gambar. Setelah program berhasil membaca metadata pada gambar, selanjutnya program akan menampilkan hasilnya. Berikut ini merupakan hasil dari metadata gambar yang sudah dan belum dimanipulasi:

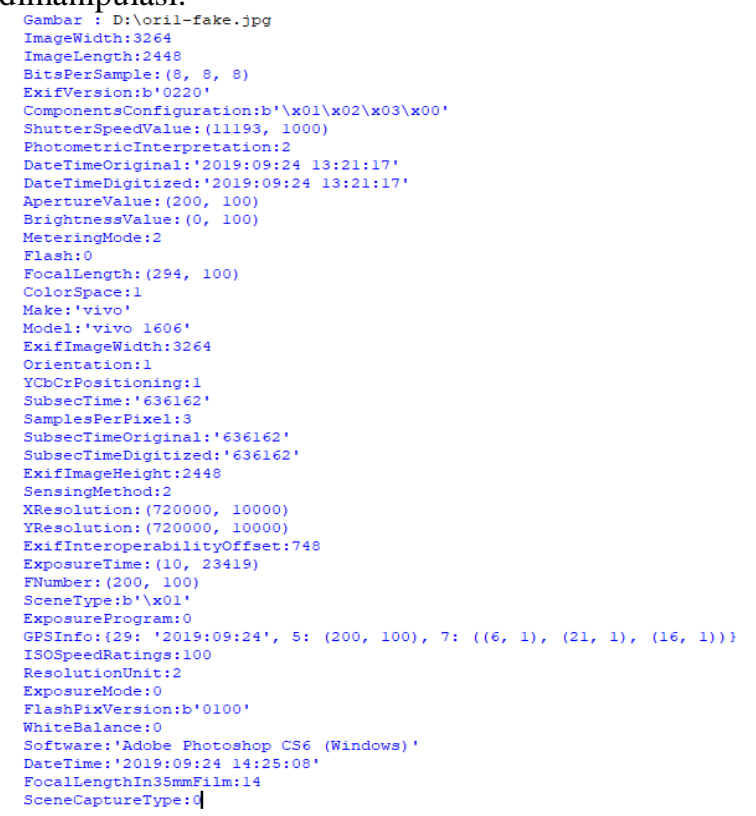

Gbr. 6 Hasil Metadata Gambar yang Dimanipulasi

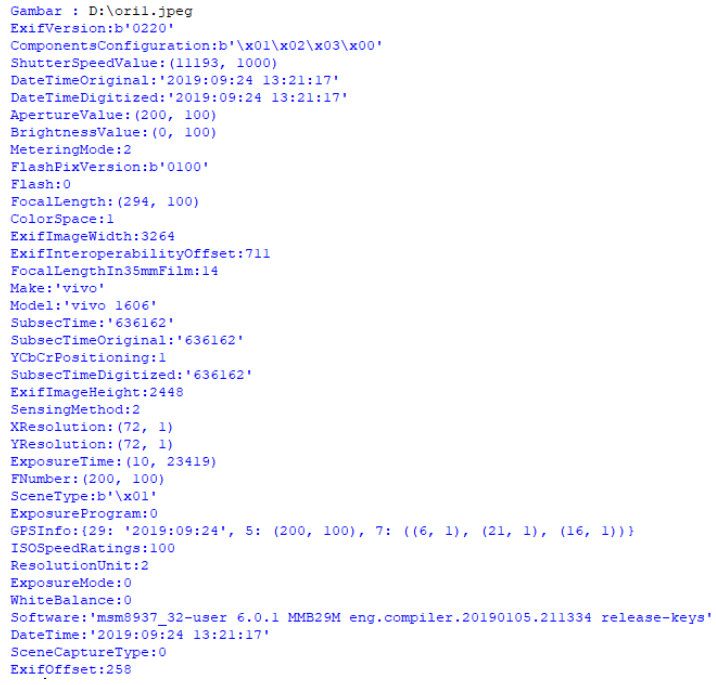

Gbr. 7 Hasil Metadata Gambar yang Belum Dimanipulasi

Setelah metadata pada file gambar berhasil ditampilkan maka kita selanjutnya melakukan analisa terhadap hasil metadata. Terlihat perbedaan dari hasil metadata pada gambar yang sudah dan belum dimanipulasi. Jumlah metadata pada file gambar yang telah dimanipulasi lebih banyak dibandingkan jumlah metadata file gambar yang belum dimanipulasi. Perbedaan metadata yang jelas terlihat dari hasil "software". Pada file gambar yang telah dimanipulasi hasil software menampilkan aplikasi yang digunakan untuk memanipulasi gambar tersebut.

\section{KESIMPULAN}

Berdasarkan hasil yang didapat dari pembahasan di atas maka penelitian ini dapat ditarik kesimpulan:

- Bahwa semua jenis gambar yang diselidiki, bisa dilihat detail metadatanya oleh algoritma EXIF metadata,

- Jumlah metadata yang dihasilkan pada gambar yang telah dimanipulasi akan lebih banyak dan juga memberikan informasi mengenai software yang digunakan dalam memanipulasi gambar.

\section{SARAN}

Adapun saran-saran yang perlu diberikan dari hasil penelitian ini yaitu:

- Dari segi hasil metadata gambar yang sudah ditemukan, perlu dikembangkan lagi menjadi lebih spesifik pembacaan metadatanya, karena setiap gambar memiliki masing-masing metadata yang berbeda.

\section{REFERENSI}

[1] P. N. Andono, T. Sutojo och M. , Pengolahan Citra Digital, Yogyakarta: ANDI, 2017.

[2] T. Sari, I. Riadi och A. Fadlil, "Forensik Citra untuk Deteksi Rekayasa File Menggunakan Error Level Analysis," Palembang, 2016.

[3] R. Santoso, "Mengenal Data EXIF / Metadata," 11 Februari $2019 . \quad$ [Online]. Available: 
https://www.keeindonesia.com/blogs/keelesson/mengenaldata-exif-metadata.

[4] G. H. A. Kusuma och I. N. Prawiranegara, "Analisa Digital Forensik Rekaman Video CCTV dengan Menggunakan Metadata dan Hash," Jakarta, 2019.

Page $\mid 88$

[5] J. Enterprise, Python untuk Programmer Pemula, Jakarta: Elex Media Komputindo, 2019.

[6] R. A. Atmoko, Dasar Implementasi Protokol MQIT Menggunakan Python dan NodeMCU, Mokosoft Media, 2019.

[7] G. N. Suryantara, Merancang Aplikasi dengan Metodologi Extreme Programmings, Jakarta: Elex Media Komputindo, 2017. 